$\frac{\text { 臨 }}{\text { 床 }}$
高 齢 者 の 突 発 性 難 聴
鈴木 幹男・北西 剛・北野 博也
矢澤代四郎・北嶋 和智

\title{
Clinical Evaluation of Sudden Deafness in the Elderly
}

\author{
Mikio Suzuki, Tsuyoshi Kitanishi, Hiroya Kitano, \\ Yoshiro Yazawa and Kazutomo Kitajima \\ (Shiga University of Medical Science)
}

To clarify the clinical features of sudden deafness in the elderly, we investigated patients' profile and the prognosis of sudden deafness retrospectively. Of 224 patients with sudden deafness between 1978 and 1999, twenty-five patients more than 65 years of age were studied. The following results were obtained:

1. The mean age of the patients was 70.8 years old, and there was no predominance in gender. The frequency of sudden deafness in the elderly has increased since 1998.

2. Of 25 patients, $10(40 \%)$ carried other systemic diseases at the onset of sudden deafness, such as diabetes mellitus, hypertension and liver dysfunction.

3. The recovery of hearing loss in aged patients with sudden deafness was significantly worse than that in patients under 65 years of age.

4. The aged patients tended to have various hearing losses in the contralateral ears. A poor prognosis of sudden deafness was noted in patients with hearing loss in the contralateral ear.

Key words : sudden deafness, elderly, systemic disease, contralateral hearing loss

はじめに

突発性難聴は突然発症する原因不明の高度感音難聴と 定義1)され，40歳代から50歳代に発生頻度が高い2)3). し かし高齢者では加齢による聴力変化をはじめ騒音暴露, 慢性中耳炎, 糖尿病などの全身疾患などから両耳に難聴 を有することが多い：このためいったん突発性難聴に罹 患すると社会生活に支障をきたしやすいと想像される.

これまで症例数が少ないためか高齢者に拈ける突発性 難聴についての検討は十分といえない4)5)。日本では今 後高齢者の比率が高くなると予測されており, 今回高齢 発症 (65歳以上) の突発性難聴臨床像を明らかにする目的 で以下の検討を行ったので報告する.

\section{対象および方法}

1978年10月から1999年 4 月までの間に滋賀医科大学耳 鼻咽喉科を発症後14日以内に受診し, 治療後聴力固定ま で経過を追えた突発性難聴新鮮例は224例(226耳)であっ た.な抏, 突発性難聴の診断基準は厚生省突発性難聴研 究班の診断基準1)を用いた. 当科では原則として入院の 上ステロイド大量投与 (ヒドロコルチゾン $600 \mathrm{mg}, 300$ $\mathrm{mg}, 100 \mathrm{mg}$ を各 3 日，基剤は低分子デキストラン使用， 他にビタミンB12, ATP製剂等を併用, 10 日目以後は ベタメタゾン $1.5 \mathrm{mg}$ 投与し, 以後適宜減量) と, 酸素 と二酸化炭素の混合ガスの吸入療法を突発性難聴に行っ ている6). ステロイド投与にて, 十分な聴力改善が得ら 
れない症例では，さらにバトロキソビンやプロスタグラ ンディン $\mathrm{E} 1$ ，アミドトリゾアートなどを適宜投与して (る7). 突発性難聴の聴力予後の判定は厚生省特定疾患 急性高度難聴調査研究班による聴力回復判定基準8 に準 じ行った. また本論文中の平均聴力レベルはこの聴力回 復判定基準で用いられている $250 \mathrm{~Hz}, 500 \mathrm{~Hz}, 1000 \mathrm{~Hz}$, $2000 \mathrm{~Hz}, 4000 \mathrm{~Hz}$ の 周波数の算術平均と定義した. この224例の5ち, 発症時年齢が 65 歳以上であった症例 （以下高齢者突難と略す)は25例(26耳：11.5\%)であった. この25例について, 1. 年龄分布, 性差, 全症例に占め る高齢者の比率の年次変化, 2 . 突発性難聴発症時治療 中の全身疾患, 3 . 突発性難聴の聴力予後, 4. 突発性 難聴の対側耳の聴力の 4 点について検討した.

\section{結 果}

1. 年龄分布, 性差, 全症例に占める高齢者の比率の 年次変化

当該期間中の全症例の内訳は男性109例(110耳), 女性 115例(116耳)であり，また平均年龄は45歳(標準偏差 17 歳)であった。高齢者突難は男性は10例(10耳)，女性は 15例(16耳)であった．性差に関して有意の差はなかった。 また年齢分布は65～79歳(平均年齢70.8歳)にわたってい た. 図 1 は全症例に占める高齢者の頻度を1978年から 5 年ごとに比較したものである．1978年から1997年までの 間は 7 ～12\%と大きな変化はなかったが，1998年以後は 28\%と増加傾向がみられた。

\section{2 . 突発性難聴発症時治療中の全身疾患}

突発性難聴発症時に治療が行われていた全身疾患では 糖尿病が 3 例, 高血圧が 7 例, 肝障害が 2 例, 脳血管障 害が 2 例，慢性腎不全が 1 例みられた。 上記の全身疾患 を1つでも有していた症例は10例(40\%)であった。10例 中 3 例で当科で用いているステロイド大量投与がこの全 身疾患のため実施できず，少量のステロイド内服，アミ ドトリゾアート投与を行った.この 3 例の聴力予後は治 癒 1 例, 不変 2 例であった.

\section{3 . 突発性難聴の聴力予後}

高齢者突難の平均初診時聴力レベルは $83 \mathrm{~dB}$ であっ た. 65 歳未満の症例では平均聴力レベルは $79 \mathrm{~dB}$ であ り，両群間に有意の差を認めなかった。初診時聴力型は 水平型 9 耳 $(34.6 \%)$, 襲型 4 耳 $(15.3 \%)$, 全壟型 4 耳 (15.3\%), 高音障害型 3 耳 $(11.5 \%)$, 山型 3 耳 $(11.5 \%)$, その他 3 耳 $(11.5 \%)$ であった. 65歳末満の症例では水平 型38耳 $(19.0 \%)$ ，龍型35耳 $(17.5 \%)$ ，全襲型23耳 $(11.5$ $\%)$ ，高音障害型32耳(16.0\%)，山型13耳(6.5\%)，その 他57耳(28.5\%)であった．高齢者と65歳未満の間に初診 時聴力型に関し有意の差はなかった．発症から受診まで の期間の平均は 5 日で 1 週間以上経過してから受診した 症例は 5 例のみであった。めまいのあった症例は 6 例 (24.0\%)であるが，全例治療後めまいは消失した。65歳 未満ではめまいは55例(27.6\%)にみられた。

治療方法はステロイド阂の大量投与を行った症例が 21 例，少量ステロイドの内服 3 例，アミドトリゾアート投

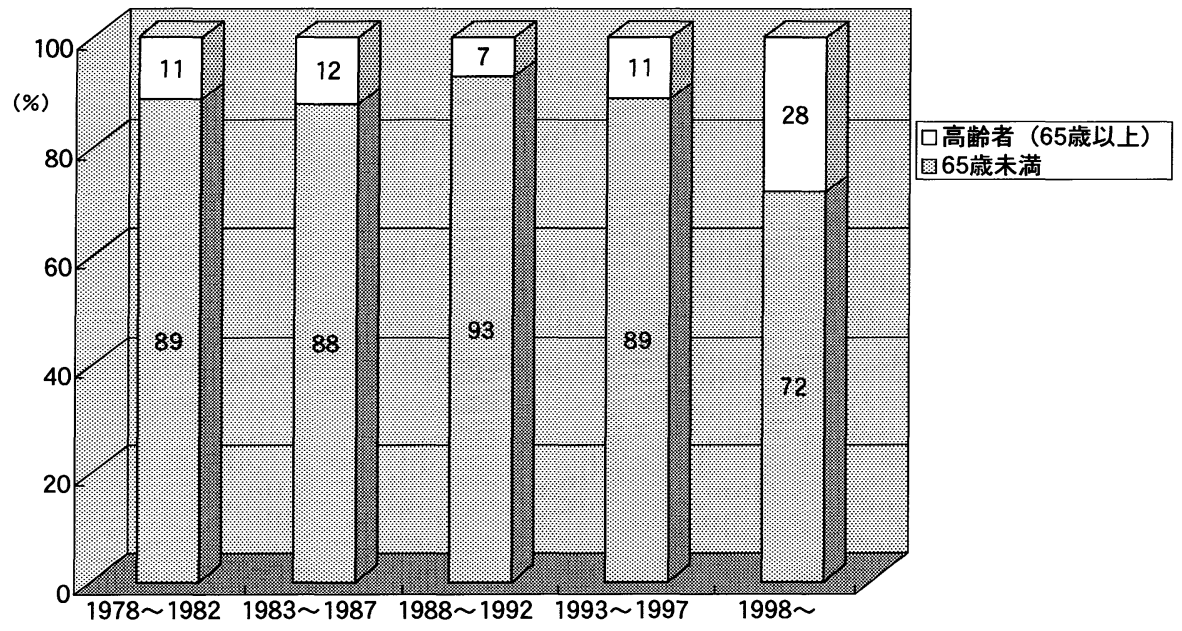

図 1 高齢者の割合の年次変化 1998年以後, 高齢者の比率が増加していた. 


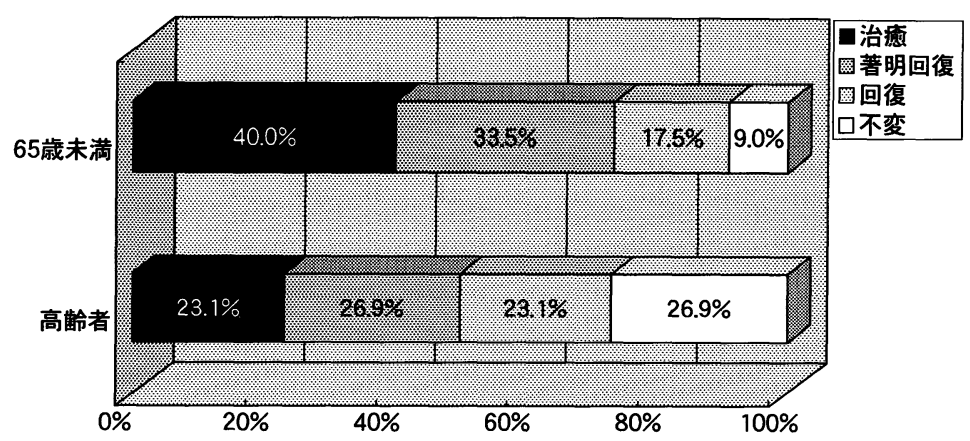

図 2 高齢者突発性難聴の聴力予後

高齢者突発性難聴は65歳未満の群より有意に治瘉・著明回復が少 なく, 不変が多かった。

与 1 例であった. 聴力固定時の平均聴力レベルは $58 \mathrm{~dB}$ であった。聴力予後は治癒 6 耳 $(23.1 \%)$, 著明回復 7 耳 (26.9\%), 回復 6 耳 $(23.1 \%)$, 不変 7 耳 $(26.9 \%)$ であっ た(図 2 )。一方，65歳未満の同時期の治療成績は治癒 80 耳 $(40.0 \%)$, 著明回復 67 耳 $(33.5 \%)$, 回復 35 耳 $(17.5 \%)$,

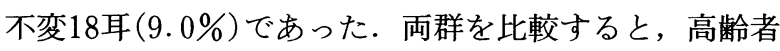
では治癒・著明回復は有意に少なく, 不変は有意に多 かった $\left(\mathrm{p}<0.05, \chi^{2}\right.$ 検定 $)$.

\section{4 . 突発性難聴の対側耳の聴力}

高齢者突難の対側耳 $(24$ 耳 : 両側例を省く)の平均聴力 レベルは $44 \mathrm{~dB}$ であった。一方 65 歳未満の突発性難聴 の健聴耳の平均聴力レベルは $18 \mathrm{~dB}$ であった. 両群間 に健聴耳の平均聴力レベルに関し有意の差を認めた $(\mathrm{p}<0.01$, Wilcoxon 検定 $)$. また, 対側耳が平均 $70 \mathrm{~dB}$ 以上の高度難聴を呈した症例は 5 例 (慢性中耳炎 3 例, 原因不明の感音性難聴 1 例, 音響外傷 1 例) であった. 対側耳は難聴がない症例(平均聴力レベル $30 \mathrm{~dB}$ 末満) が 5 耳, 難聴がある症例が19耳であった。対側耳聴力像 の内訳を表 1 亿示す. 表に示すよらに対側耳には老人性 難聴, 慢性中耳炎, 原因不明の感音性難聴などの難聴が
多くみられた。対側耳に難聴がない 5 例では突発性難聴 の予後は治癒 2 耳, 著明回復 2 耳, 回復 1 耳と良好で あった。一方, 対側耳に平均 $70 \mathrm{~dB}$ 以上の難聴があっ た 5 例では突発性難聴の予後は著明回復 1 耳, 回復 2 耳, 不変 2 耳で予後不良であった.

\section{考察}

厚生省の人口動態調査 ${ }^{9}$ によれば，1980年には老年人 ロが9.1\%であったものが，1997年には15.7\%と著明に 増加している. 2010年にはさらに $22.6 \%$ まで上昇すると 推計されている. 今回のわれわれの調査では1997年まで は高齢者突難の比率は著変なかったが, 1998年以後増加 して和り, 人口構成の変化とともに今後増加すると予測 された.

われわれの高齢者突難の症例は平均年齢が高いことを 反映して, 全症例の $40 \%$ が全身疾患を抱えていた.この 5ち, 糖尿病や肝障害を持つ症例では罹病期間が長く, 糖尿病例では血管障害, 神経障害, 腎機能低下を, 肝障 害例では肝硬変をきたしていた．このため 3 例で治療方 法が制限され， 3 例の聴力予後は不良であった。このこ

表 1 対側耳の聴力

\begin{tabular}{l|c|lll}
\hline \hline 難聴なし & 5 耳 & & & \\
\hline 難聴あり & 19 耳 & 混合性難聴 $(4$ 耳) & 慢性中耳炎 & 4 耳 \\
\hline & & 感音性難聴 $(15$ 耳 $)$ & 老人性難聴 & 9 耳 \\
& & & 原因不明の感音性難聴 & 4 耳 \\
& & & ストマイ難聴 & 1 耳 \\
& & & 音響外傷 & 1 耳 \\
\hline
\end{tabular}


とから高齢者突難の予後が不良である理由の一つに全身 合併症による治療方法の制限があると考兄られる。 また 突発性難聴の原因は不明であるが血流障害も一因と考光 られている7)。糖尿病例や肝障害例では血管病変をもつ ことから，全身疾患にともなら血管障害が高齢者突難の 予後を悪くしているとも考兄られる.

高齢者突難では, 従来聴力予後不良の指標10) とされ る初診時聴力レベル, 聴力型, めまいの頻度は65歳未満 の突発性難聴と差がなく，また発症から初診までの期間 は平均 5 日で比較的早期に受診した症例が多かった。 上 述の全身疾患のため十分治療できなかった 3 症例を除い ても高齢者突難の聴力予後は悪く, 他に原因があると思 われる. 高齢者突難の対側耳を調べると平均聴力レベル が $44 \mathrm{~dB}$ と悪く, また $70 \mathrm{~dB}$ 以上の難聴を持つ症例が $20.8 \%$ によらた。.さらに, 対側耳の聴力障害の程度が 強い症例ほど聴力予後が悪い傾向がみられた. 以上を考 党あわせる, 高齢者突難例では突難の発症以前から内 耳機能が低下して招り，このことが内耳障害時の治療に 対する反応不良をもたらすと推察された。

過去の報告では高齢者突難の聴力予後は他の年齢層と 差がないとするものもある4)が，多数は高齢者では聴力 予後が不良としている2335). 今回の検討でも高齢者突難 の聴力予後が明らかに不良であった。 これらの症例では 対側耳に難聴を持つことが多く, 突発性難聴治療後難聴 が改善しない場合は補聴器のフィッティングや定期的な 聴力管理が必要と推察された。

$$
\text { まとめ }
$$

1978年10月から1999年 4 月までの間に当科を発症後 14 日以内に受診した突発性難聴新鮮例224例 (226耳)のらち, 高齢者25例(26耳)の突発性難聴の臨床像を検討し以下の 結果を得た.

1. 発症時年齢の平均は70.8歳で, 男女差はなかった. 1978年から1997年までは 7 ～12\%で変化なかったが， 1998年以後 $28 \%$ と増加していた。

2. 糖尿病や高血圧などの全身疾患の合併は 10 例 ( 40
\%)にみられた。3例で全身疾患のため，治療法が制限 され，聴力予後も不良であった。

3 . 高齢者突発性難聴の聴力予後は65歳未満の症例と 比し有意に悪かった.

4. 突発性難聴の対側耳は難聴を持つことが多く，対 側耳に難聴が存在する方が突発性難聴の予後が不良で あった。

本研究の一部は文部省科学研究費 (09877330)を用いて行われ た.

\section{参考文献}

1) 三宅 弘：総括研究報告. 厚生省特定疾患突発性難聴調查 研究班昭和 48年度研究報告書. 1 3, 1973.

2) 泰地秀信, 神崎 化: 突発性難聴の予後の回費分析. 日耳 鼻 $91: 1023 \sim 1030,1988$.

3 ）小笠原秀樹, 森下賢治, 石井 歓, 他 : 突発性難㯖におけ る統計学的検討. 日耳鼻 $96: 914 \sim 921,1993$.

4 ）川端五十鈴, 八木昌人, 川島貴之, 他 : 高龄者の突発性難 聴. 日耳鼻 $97: 233 \sim 239,1994$.

5 ）小野雄一, 平山方俊, 佐野 㲠, 他: 高齢者の突発性難聴. Otol Jpn $4:$ 415, 1997.

6 ）糟谷憲邦, 鈴木幹男, 北西 剛, 他 : 初診以後聴力障害が 進行した突発性難聴. 耳鼻臨床 $92 ： 1049 \sim 1057,1999$.

7 ）鈴木幹男, 北西 剛, 佐伯紀子, 他 : 突発性難聴飞対する 脱線維素原療法の経験. 耳鼻臨床 $87: 711 \sim 717,1994$.

8 ）野村恭也：総括研究報告. 厚生省特定疾患急性高度難聴調 査研究班昭和 59 年度研究業績報告書. 1 3, 1985.

9 ）厚生統計協会: 第 2 編衛生の主要指標第 1 章人口静態. 国 民衛生の動向 (厚生統計協会編). $37 \sim 42$ 頁, 厚生統計協会, 東京, 1998.

10）柳田則之：突発性難聴の臨床．耳鼻臨床 $78 ： 299 \sim 311$, 1985.

$$
\left(\begin{array}{l}
\text { 原稿受付 : 平成 } 11 \text { 年 } 7 \text { 月 } 23 \text { 日 } \\
\text { 原稿採択 : 平成 } 11 \text { 年 } 8 \text { 月 } 25 \text { 日 } \\
\text { 別刷請求先 : 鉿木幹男 } \\
\text { 干520-2192 滋賀県大津市瀬田月輪町 } \\
\text { 滋賀医科大学耳鼻咽喉科学教室 }
\end{array}\right)
$$

